\title{
HUBUNGAN KEMUDAHAN PENGGUNAAN M-BANKING DENGAN PERILAKU KONSUMTIF PADA MAHASISWA UNIVERSITAS NEGERI PADANG PENGGUNA SHOPEE
}

\section{THE CORRELATION OF EASY OF USE M-BANKING WITH CONSUMPTION BEHAVIOR IN STUDENTS OF STATE UNIVERSITY OF PADANG USERS OF SHOPEE}

\author{
Desfayanti \\ Jurusan Psikologi, Universitas Negeri Padang/desfayanti@gmail.com
}

\begin{abstract}
Introduction This study aims to examine the relationship between the ease of using m-banking with consumptive behavior in Padang State University students shopee users. Consumptive behavior is defined as the activity of buying an item with unreasonable considerations and not based on needs.

Method This research is a quantitative research with a correlational research design. This research was conducted on 51 Padang State University students aged 18-21 years who are shopee users and make payments via mobile banking. The scale used is the ease of use of mobile banking and the consumptive behavior scale. Data were analyzed by using Person Product Moment correlation.
\end{abstract}

Result This study found that there is a positive relationship between the ease of using mobile banking and the consumptive behavior of Padang State University students who use shopee. With a value of $(r)=$ $0.351(p)=0.012(p=0.012<0.05)$.

Conclussion That is the higher the level of ease of use of mobile banking, the higher the level of consumptive behavior of Padang State University students who use shopee, and vice versa.

Keywords: Consumptive behavior, college student, mobile banking

\section{ABSTRAK}

Pendahuluan Penelitian ini bertujuan untuk menguji hubungan antara kemudahan penggunaan mbanking dengan perilaku konsumtif pada mahasiswa pengguna shopee Universitas Negeri Padang. Perilaku konsumtif diartikan sebagai kegiatan membeli suatu barang dengan pertimbangan yang tidak masuk akal dan tidak berdasarkan kebutuhan.

Metode Penelitian ini merupakan penelitian kuantitatif dengan desain penelitian korelasional. Penelitian ini dilakukan terhadap 51 mahasiswa Universitas Negeri Padang berusia 18-21 tahun yang merupakan pengguna shopee dan melakukan pembayaran melalui mobile banking. Skala yang digunakan adalah skala kemudahan penggunaan mobile banking dan skala perilaku konsumtif. Data dianalisis dengan menggunakan korelasi Person Product Moment.

Hasil Penelitian ini menemukan bahwa terdapat hubungan positif antara kemudahan penggunaan mobile banking dengan perilaku konsumtif mahasiswa Universitas Negeri Padang pengguna shopee. Dengan nilai $(\mathrm{r})=0,351(\mathrm{p})=0,012(\mathrm{p}=0,012<0,05)$.

Kesimpulan Penelitian menunjukkan semakin tinggi tingkat kemudahan penggunaan mobile banking maka semakin tinggi pula tingkat perilaku konsumtif mahasiswa Universitas Negeri Padang yang menggunakan shopee, begitu pula sebaliknya.

\section{Pendahuluan}

Situs belanja online dewasa ini populer di kalangan masyarakat Indonesia. Turban, Lee, King \& Mc Kay (2008) mendefinisikan belanja online sebagai proses pembelian yang melibatkan transaksi antara penjual dan pembeli melalui platform digital di internet, dan dapat dilakukan dimanapun dan kapanpun. Harahap (2018) mendefinisikan belanja 
online sebagai suatu proses transaksi yang dilakukan melalui media berupa situs jual beli jejaring sosial yang menyediakan barang atau jasa yang akan diperjualbelikan. Berdasarkan data yang diperoleh melalui Social Research and Monitoring Soclab, Kementerian Komunikasi dan Informasi (2015) jumlah pengguna internet di Indonesia sebanyak 93,4 juta dan $(77 \%)$ diantaranya digunakan untuk mencari informasi produk dan belanja online. Dengan jumlah konsumen belanja online sebanyak 7,4 juta orang.

Darian menyatakan banyaknya masyarakat Indonesia yang memilih untuk berbelanja online dibanding dengan berbelanja ke toko langsung, dikarenakan kemudahan yang diberikan (Hermawan, 2017; Arisandy \& Hurriyati, 2017). Farida dan Subroto (2018) berpendapat bahwa kelebihan dalam berbelanja online yaitu harga yang ditawarkan lebih murah, lebih menghemat waktu, tenaga, kemudahan penawaran dan pembayaran yang diberikan, praktis dan lebih fleksibel jika dibandingkan dengan berbelanja secara konvensional.

Bashir, Mehboob, dan Bhatti (2015) menambahkan keuntungan dari belanja online yaitu toko online menyediakan produk dengan detail informasi dan banyak pilihan, sehingga konsumen dapat membandingkan harga dan produk secara online.

Berdasarkan hasil survei penulis tentang pengguna aplikasi belanja online terbanyak pada mahasiswa, menunjukkan hasil bahwa mayoritas mahasiswa menggunakan aplikasi Shopee untuk berbelanja online. Hal ini sejalan dengan survei yang dilakukan oleh Kompas.com (2018) tentang tiga $e$-commerce yang paling diminati oleh konsumen, dan Shopee unggul dibanding aplikasi lainnya.

Mahasiswa tergolong kelompok konsumen usia remaja (Lisma \& Haryono, 2016). Remaja merupakan masa peralihan dari anak-anak menuju dewasa yang ditandai dengan perubahan fisik, emosional, dan pola pikir (Santrock, 2010). Usia remaja terbagi atas tiga tahap yaitu remaja awal berusia 12-15 tahun, remaja madya berusia 15-18 tahun, dan remaja akhir berusia 18-21 tahun. Dengan demikian, mahasiswa tergolong dalam usia remaja akhir yang berusia 18-21 tahun, dengan karakteristik yang mudah dipengaruhi dan labil, sehingga remaja juga sangat mudah untuk dipengaruhi untuk membeli suatu barang tanpa memikirkan dengan matang terlebih dahulu, tidak jarang remaja juga mudah menjadi orang yang konsumtif. (Kanserina, 2015).

Salah satu kelompok usia remaja yaitu mahasiswa. Mahasiswa merupakan pelajar di suatu perguruan Tinggi. Dalam aktivitasnya sehari-hari mahasiswa tidak terlepas dari kegiatan jual beli secara online. Menurut Komala dan Sugilar (2020) bahwa mahasiswa sebagai konsumen belanja online yang tinggi kebutuhannya dalam belanja online serta mendapatkan kemudahan akses yang ditawarkan oleh aplikasi belanja online.

Berdasarkan hasil survei, penulis menemukan fenomena yang serupa di kalangan mahasiswa, dimana mahasiswa lebih tertarik untuk berbelanja online dibandingkan berbelanja ke toko langsung karena harga lebih murah, praktis dan efisien, menghemat waktu dan tenaga, tersedia banyak pilihan, diskon, pilihan yang beragam, gratis ongkos kirim, dan bisa dilakukan dimana saja, dan metode pembayaran yang beragam.

Berbagai metode pembayaran yang ditawarkan shopee adalah transfer bank, shopeepay, pay later, credit card, cash on delivery (CoD), dan lain sebagainya. Namun Elnino, Lesawengen, dan Lasut (2020) dalam penelitiannya menemukan bahwa mayoritas pembayaran dilakukan melalui transfer bank. Selain aplikasi belanja online, bank juga sudah menyediakan layanan transfer antar rekening melalui smartphone dengan aplikasi mobile banking (m-banking).

Wulandari, Putri, Novandriani, dan Moeliono (2017) menyatakan hadirnya mobile banking semakin memudahkan 
masyarakat dalam melakukan melakukan transaksi pembayaran belanja online. Rahayu (2015) mendefinisikan mobile banking sebagai bentuk layanan jasa bank yang memudahkan nasabah untuk memperoleh informasi, melalui jaringan internet. Salah satu fasilitas yang ditawarkan m-banking yaitu transfer antar bank. Dengan kata lain, jika pengguna shopee ingin membayar barang yang akan dibeli, dan dia juga merupakan pengguna m-banking, maka dia dapat langsung mentransfer uang dari rekeningnya ke rekening penjual melalui layanan transfer pada aplikasi m-banking.

Karena banyaknya kemudahan tersebut, dapat menimbulkan beberapa masalah seperti munculnya perilaku konsumtif di kalangan mahasiswa (Harahap, 2018). Sumartono (2002) mendefinisikan perilaku konsumtif sebagai sebuah aktivitas membeli suatu barang dengan pertimbangan yang kurang masuk akal dan bukan berdasarkan pada kebutuhan.

Chita, David, dan Pali (2015) mendefinisikan perilaku konsumtif sebagai perilaku manusia yang cenderung untuk melakukan konsumsi atau membeli sesuatu secara berlebihan di luar kebutuhan seharihari. Sulistianingsih (2016) menyatakan perilaku konsumtif muncul karena mahasiswa cenderung memiliki hasrat yang besar untuk memiliki barang-barang tanpa memperhatikan kebutuhannya.

Berdasarkan fenomena yang telah dijabarkan di atas, penulis tertarik untuk meneliti tentang hubungan kemudahan penggunaan $\mathrm{M}$-banking dengan perilaku konsumtif pada mahasiswa Universitas Negeri Padang pengguna Shopee.

\section{Metode}

Penelitian ini dilakukan di Universitas Negeri Padang dengan menggunakan metode kuantitatif. Penelitian kuantitatif didefinisikan sebagai penelitian yang datanya dinyatakan dalam bentuk numerik, kemudian dianalisis dengan menggunakan teknik statistik (Sugiyono, 2013).
Variabel independen dalam penelitian ini adalah penggunaan mobile banking dan variabel dependen adalah perilaku konsumtif. Variabel independen adalah variabel bebas yang memberikan pengaruh atau yang menjadi sebab timbulnya variabel terikat, sedangkan variabel dependen adalah variabel terikat yang menjadi akibat dari adanya variabel bebas (Sugiyono, 2013).

Populasi didefinisikan Sugiyono (2013) sebagai wilayah generalisasi yang memiliki suatu kesamaan atau karakteristik tertentu. Populasi dalam penelitian ini adalah seluruh mahasiswa aktif Universitas Negeri Padang pengguna Shopee. Sampel pada penelitian ini berjumlah 51 orang yang berkuliah di Universitas Negeri Padang.

Dalam menentukan sampel penelitian, peneliti menggunakan teknik purposive sampling karena penentuan sampel pada penelitian ini didasari oleh pemilihan karakteristik tertentu yang terkait dengan karakteristik populasi Sugiyono (2013). Karakteristik sampel pada penelitian ini yaitu mahasiswa aktif Universitas Negeri Padang, berusia 18-21 tahun yang menggunakan platform belanja online shopee, dan melakukan pembayaran melalui aplikasi mobile banking.

Teknik pengambilan data pada penelitian ini menggunakan kuesioner online atau google form tipe likert dengan lima pilihan jawaban yaitu SS (sangat setuju), S (setuju), R (ragu-ragu), TS (tidak setuju), STS (sangat tidak setuju).

Instrumen penelitian ini menggunakan skala perilaku konsumtif Sumartono (2002), yang terdiri dari aspek pembelian impulsif, pembelian irrasional, dan status sosial. Sedangkan skala mobile banking dikembangkan dari teori Davis yang diadaptasi dari penelitian Syifa (2019) yang terdiri dari aplikasi mudah digunakan, layanan dapat dijangkau dari mana saja, murah, aman, dan dapat diandalkan.

Teknik analisis data pada penelitian ini menggunakan korelasi product moment. Korelasi product moment yang digunakan untuk mencari hubungan atau menjawab 
hipotesis penelitian (Sugiyono, 2013). Analisis statistik yang digunakan dalam penelitian ini adalah dengan menggunakan Statistical Product and Service Solution (SPSS) versi 16.0.

Hipotesis penelitian ini terbagi 2 yaitu Ha: Terdapat hubungan kemudahan penggunaan mobile banking terhadap perilaku konsumtif pada mahasiswa Universitas Negeri Padang pengguna Shopee. Sedangkan H0: Tidak terdapat hubungan kemudahan penggunaan mobile banking terhadap perilaku konsumtif pada mahasiswa Universitas Negeri Padang pengguna Shopee.

\section{Hasil}

Sampel pada penelitian ini berjumlah 51 orang mahasiswa Universitas Negeri Padang usia 18-21 tahun pengguna shopee dan melakukan pembayaran melalui mobile banking. Penelitian ini memperoleh hasil bahwa terdapat hubungan kemudahan penggunaan mobile banking terhadap perilaku konsumtif pada mahasiswa Universitas Negeri Padang pengguna shopee. Dengan memperoleh hasil $\mathrm{r}=0.351$ dengan signifikansi $\mathrm{p}=0.012(\mathrm{p}<0.05)$ yang menyatakan bahwa Ha diterima dan H0 ditolak.

Pada penelitian ini menyatakan bahwa terdapat hubungan positif yang signifikan antara kemudahan penggunaan mobile banking dengan perilaku konsumtif pada mahasiswa Universitas Negeri Padang pengguna Shopee. Itu artinya semakin tinggi tingkat kemudahan penggunaan mobile banking semakin tinggi pula tingkat perilaku konsumtif mahasiswa. Begitupun sebaliknya semakin rendah tingkat kemudahan penggunaan mobile banking semakin rendah pula tingkat perilaku konsumtif mahasiswa.

Sebelum melakukan analisis korelasi product moment untuk meyakinkan adanya hubungan antara dua variabel tersebut, peneliti melakukan uji reliabilitas, normalitas dan linearitas terlebih dahulu. Syarat untuk dapat melakukan uji statistik parametrik yaitu telah melakukan uji reliabilitas, normalitas, dan linearitas. Jika syarat tersebut sudah terpenuhi maka data baru dapat dianalisis dengan menggunakan statistik parametrik salah satunya dengan korelasi pearson product moment.

Sugiyono (2013) menyatakan reliabilitas digunakan untuk melihat sejauh mana suatu instrumen dapat mengukur sesuatu secara berulang dengan memperoleh hasil yang konsisten. Reliabilitas alat ukur dalam penelitian ini diukur dengan menggunakan Cronbach Alpha dengan bantuan SPSS. Selanjutnya, setelah diuji dan memperoleh hasil, peneliti memilih aitem-aitem yang lolos yang kemudian dianalisis. Hasil uji reliabilitas dapat kita lihat pada tabel 1. di bawah ini :

Tabel 1. Uji Reliabilitas

\begin{tabular}{|c|c|c|}
\hline Variabel & $\begin{array}{c}\text { Cronbach } \\
\text { Alpha }\end{array}$ & $\begin{array}{c}\text { Index } \\
\text { Descrimina } \\
\text { tion Item }\end{array}$ \\
\hline $\begin{array}{l}\text { Kemudahan } \\
\text { Penggunaan } \\
\text { Mobile } \\
\text { Banking } \\
\end{array}$ & 0,760 & $\begin{array}{c}0,582- \\
0,826\end{array}$ \\
\hline $\begin{array}{l}\text { Perilaku } \\
\text { Konsumtif }\end{array}$ & 0,733 & $\begin{array}{c}0,446- \\
0,793\end{array}$ \\
\hline
\end{tabular}

Berdasarkan tabel diatas dapat dilihat bahwa pada variabel Kemudahan penggunaan mobile banking diperoleh nilai cronbach alpha sebesar 0.760 dengan nilai index descrimination item 0.582 sampai 0.826 . Pada variabel perilaku konsumtif diperoleh nilai cronbach alpha sebesar 0.733 dengan nilai index descrimination item 0.466 sampai 0.793 , dapat disimpulkan bahwa data yang diperoleh bersifat reliabel.

Tabel 2. Uji Normalitas Skala Kemudahan Penggunaan mobile dengan Perilaku Konsumtif

\begin{tabular}{lcc}
\hline \multicolumn{1}{c}{ Variabel } & p & Sebaran \\
\hline $\begin{array}{l}\text { kemudahan } \\
\text { penggunaan }\end{array}$ & & \\
$\begin{array}{l}\text { mobile banking } \\
\text { dan perilaku }\end{array}$ & 0,106 & $0,582-0,826$ \\
konsumtif & & \\
\hline
\end{tabular}


Hasil uji normalitas data kemudahan penggunaan mobile banking dan perilaku konsumtif dan menggunakan kolgomorov smirnov KS-Z, sebesar 1,212 dengan nilai $\mathrm{p} 0,106(\mathrm{p}>0,05)$ maka dapat disimpulkan bahwa data kemudahan penggunaan mobile banking dan perilaku konsumtif berdistribusi normal.

Tabel 3. Uji Linearitas Skala Kemudahan Penggunaan Mobile dengan Perilaku Konsumtif

\begin{tabular}{ccccc}
\hline N & df & Mean Square & F & Sig \\
\hline 51 & 1 & 854.694 & 6.434 & 0,017 \\
\hline
\end{tabular}

Berdasarkan tabel di atas, diperoleh nilai $\mathrm{F}$ sebesar 6.434 dengan signifikansi sebesar 0.017. Hasil di atas menunjukkan bahwa nilai $\mathrm{p}<0.05$, yang berarti bahwa kemudahan penggunaan mobile banking dan perilaku konsumtif linear.

Setelah diperoleh hasil bahwa data berdistribusi normal dan linear, selanjutnya dilakukan uji hipotesis. Data dianalisis menggunakan uji korelasi pearson product Moment. Hasil yang didapatkan dari uji hipotesis dapat dilihat pada tabel berikut:

Tabel 4. Hasil Uji Korelasi Person Product Moment

\begin{tabular}{ccc}
\hline $\mathbf{p}$ & $\boldsymbol{\alpha}$ & Nilai korelasi (r) \\
\hline 0,012 & 0,05 & 0,351 \\
\hline
\end{tabular}

Tabel di atas merupakan tabel hasil uji analisis korelasi product moment. Dari tabel diatas terlihat bahwa nilai sig. yang diperoleh adalah 0.012 (nilai sig. < 0.05). Hal ini menunjukkan bahwa Ha diterima,. sehingga terdapat hubungan positif antara kemudahan penggunaan mobile banking dan perilaku konsumtif mahasiswa Universitas Negeri Padang pengguna Shopee.

Hal tersebut berarti semakin tinggi tingkat kemudahan penggunaan mobile banking maka semakin tinggi pula tingkat perilaku konsumtif konsumtif mahasiswa Universitas Negeri Padang pengguna shopee, dan sebaliknya.

\section{Diskusi}

mobile $\begin{array}{r}\text { Kemudahan } \\ \text { banking }\end{array} \begin{gathered}\text { penggunaan } \\ \text { diyakini dari }\end{gathered}$ dapat mempermudah pengguna dimana pengguna tidak memerlukan usaha keras dalam menggunakannya. Davis (Syifa, 2019) berpendapat bahwa terdapat empat unsur yang menjadi indikator dalam kemudahan penggunaan mobile banking yaitu mudah dipahami, fleksibel, dapat mengontrol pekerjaan, dan mudah digunakan.

Persepsi tersebut dapat dilihat dari hasil penelitian berupa kuisioner google form, bahwa banyak responden memilih sangat setuju dengan penggunaan mobile banking dapat mengendalikan pekerjaan mereka dan dapat mempercepat proses transaksi pembayaran online.

$$
\text { Pengguna yakin dengan }
$$

menggunakan mobile banking dapat mempermudah mereka dalam konsumsi secara online. Sehingga mobile banking dapat dikatakan sebagai suatu sistem dapat meningkatkan produktivitas bagi yang menggunakannya, maka mobile banking ini dapat memberi pengaruh terhadap perilaku konsumtif penggunanya. Teknologi cukup berperan dalam membentuk masyarakat kearah yang lebih konsumtif.

Ritzer (Syifa, 2019) menyatakan alat konsumsi baru bersifat modern dan rasional. Alat konsumsi baru bersifat dapat menghemat waktu, tenaga, dan biaya. Mahasiswa sebagai anak muda tentu tidak ingin melewatkan kemajuan teknologi. Hal ini memudahkan mahasiswa dalam melakukan transaksi pembayaran atau pembelian tanpa dibatasi waktu. Penelitian Prakoso (2013) menemukan hasil bahwa pemanfaatan teknologi menjadi faktor pendorong dalam terbentuknya perilaku konsumtif mahasiswa.

Perilaku konsumtif merupakan perilaku membeli atau menggunakan suatu barang dengan pertimbangan yang kurang masuk akal dan pembelian berdasarkan keinginan bukan kebutuhan. Dilihat dari masing-masing aspek perilaku konsumtif yang dikembangkan berdasarkan teori Sumartono (2002) pada aspek yang pertama 
yaitu pembelian impulsif. Menurut Utami (2006) pembelian impulsif dapat terjadi ketika konsumen melihat suatu produk atau brand tertentu yang terlihat menarik sehingga konsumen merasa ingin memiliki produk atau brand tersebut. sehingga pada akhirnya, konsumen tersebut membeli produk atau brand tersebut tanpa direncanakan.

Hal ini dapat terjadi karena berbagai faktor misalnya ada diskon atau subjek memiliki voucher, cashback dan gratis ongkos kirim yang sia-sia jika tidak digunakan. Hal ini senada dengan hasil penelitian Rizkallah dan Truong (2010) yang menyatakan bahwa konsumen tertarik untuk berbelanja karena ingin mendapatkan kupon, diskon, dan bonus pembelian. Lejoyeux, Haberman, Solomon, dan Ades (1999) memperoleh hasil bahwa seseorang berperilaku konsumtif dapat disebabkan karena rasa takut melewatkan kesempatan untuk membeli barang tersebut yang mungkin tidak akan tersedia lagi di kemudian hari.

Aspek kedua yaitu pembelian irrasional. Pembelian irrasional ini dapat terjadi karena adanya suatu motif yang lebih di pengaruhi oleh faktor emosional dibandingkan faktor kognitif. Rasimin (1995) berpendapat bahwa motif juga dapat menjadi salah satu aspek yang menyebabkan seseorang untuk berperilaku konsumtif. Nugroho (2003) mendefinisikan motif emosional sebagai suatu motif yang dipengaruhi oleh rasa penasaran, sehingga konsumen terkesan terburu-buru dalam membeli produk atau brand tersebut tanpa berpikir matang terlebih dahulu.. Jadi pembelian irrasional ini terjadi dengan hanya berlandaskan emosi semata. Hal ini senada dengan hasil penelitian Lejoyeux, Ades, Tassain, dan Solomon (1996) yang menyatakan bahwa perilaku konsumtif dalam berbelanja online juga dapat terjadi karna penjual dan pembeli tidak bertemu secara langsung karna salah satu fitur belanja online menawarkan kerahasiaan yang terjaga sehingga keluarga pembeli tidak akan mengetahui bahwa anggota keluarganya sudah berperilaku konsumtif dengan membeli barang-barang yang tidak ia butuhkan.

Selain itu seseorang dengan perilaku konsumtif diketahui membeli sesuatu tidak didasari kebutuhan atau manfaat dari hal yang dibeli melainkan karena adanya keinginan mengakuisisi produk yang dibeli. Lejoyeux dan Weinstein (2010) memperoleh hasil penelitian yang sama, yaitu seseorang berperilaku konsumtif dikarenakan kondisi yang terdesak sehingga tidak berpikir dengan matang terlebih dahulu sebelum membeli serta konsumen tidak lagi dapat menahan godaan dari dalam dirinya.

Billieux, Rochat, Rebetz, dan Linden (2008) dalam penelitiannya menemukan bahwa seseorang berperilaku konsumtif dikarenakan tiga hal yaitu karena terdesak, karena tidak merencanakan pembelian sebelumnya, dan karena tidak memikirkan dengan matang sebelum pembelian.

Aspek ketiga yaitu status sosial. Konsumen berperilaku konsumtif dengan membeli produk atau brand tertentu untuk menunjang status sosial di dalam suatu lingkungan atau kelompok. Dengan menggunakan produk atau brand tersebut, konsumen akan merasa dipandang dan memiliki status sosial yang baik. Hal ini sejalan dengan hasil penelitian Adiningtyas, Sunaryanto, dan Nopianti (2018) yang menyatakan bahwa seseorang berperilaku konsumtif karena ingin terlihat modern, kaya, dan memiliki status sosial yang tinggi.

\section{Kesimpulan}

Sehingga dapat disimpulkan bahwa terdapat hubungan positif antara kemudahan penggunaan mobile banking dan perilaku konsumtif mahasiswa Universitas Negeri Padang pengguna shopee. Hal tersebut berarti, semakin tinggi tingkat kemudahan penggunaan mobile banking maka semakin tinggi pula tingkat perilaku konsumtif konsumtif mahasiswa 
Universitas Negeri Padang pengguna shopee, dan sebaliknya.

\section{Saran}

Saran bagi penelitian selanjutnya yaitu agar mengkaji hubungan antara kemudahan penggunaan mobile banking dan perilaku konsumtif mahasiswa Universitas Negeri Padang pengguna shopee ditinjau dari jenis kelamin dengan pengambilan data langsung ke lapangan dan tidak menggunakan google form.

\section{Daftar Pustaka}

Adiningtyas, R. A., Sunaryanto, H., \& Nopianti, H. (2018). Perilaku konsumtif pelajar sekolah menengah atas. Jurnal Sosiologi Nusantara, 4 (1): 1-9. Doi: 10.33369/jsn.4.1.1-9.

Arisandy, D. \& Hurriyati, D. (2017). Hubungan antara kontrol diri dengan impulsive buying pada mahasiswi fakultas psikologi di perguruan tinggi wilayah palembang yang melakukan belanja online. Prosiding Seminar Nasional Penelitian dan Pkm Kesehatan: 31-39. eISSN 2477-2356.

Bashir, Mehboob, \& Bhatti. (2015). Effects of online shopping trends on consumer-buying behavior: an empirical study of pakistan. Journal of Management And Research, 2 (2): 124.

Billieux, J., Rochat, L., Rebetz, M.L., \& Linden, V.D. (2008). Are all facets of impulsivity related to self-reported compulsive buying behavior? Personality and Individual Differences, 44: 1432-1442.

Chita, R. C. M., David, L. \& Pali, C. (2015). Hubungan antara self control dengan perilaku konsumtif online shopping produk fashion pada mahasiswa fakultas kedokteran Universitas SAM Ratulangi angkatan 2011. Jurnal E-Biomedik, 3 (1): 297 302.
Elnino, S.R., Lesawengen, L., \& Lasut, J.J. (2020). Tindakan konsumtif dalam aktivitas belanja online mahasiswa di fakultas ilmu sosial dan politik Universitas Sam Ratulangi Manado. Jurnal Holistik, 13 (3): 1-15.

Farida, M. N., \& Subroto, W. T. (2019). Effect of mobile banking and online shopping on consumer behavior. International Journal of Educational Research Review, 154-161. https://doi.org/10.24331/ijere.517977.

Harahap, D. A. (2018). Perilaku belanja online di indonesia: studi kasus. Jurnal Riset Manajemen Sains Indonesia (JRMSI), 9 (2): 193-213. Doi: 10.21009/JRMSI.

Hermawan, H. (2017). Sikap konsumen terhadap belanja online. Wacana, 16 (1): 136-147.

Kementerian Komunikasi dan Informasi Republik Indonesia. (2015). Laporan tahunan 2015. Jakarta.

Komala, C. \& Sugilar, H. (2020). Kategori dan layanan e-commerce terhadap daya beli di kalangan mahasiswa. Jurnal Benefita, 5 (1): 129-139.

Kompas.com. (2018). Ini 3 e-commerce yang paling dikenal masyarakat Indonesia. Diakses tanggal 5 Oktober 2020 melalui https://ekonomi.kompas.com/read/201 8/11/08/172007426/ini-3-e-commerceyang-paling-dikenal-masyarakatindonesia.

Lejoyeux, M., Ades, J., Tassain, V., \& Solomon, J. (1996). Phenomenology and 'psychopathology of uncontrolled buying. Am J Psychiatry, 155: 15241529.

Lejoyeux, M., Haberman, N., Solomon, J., \& Ades, J. (1999). Comparison of buying behavior in depressed patients presenting with or without compulsive buying. Compr Psychiatry, 40: 51-56. 
Lejoyeux, M. \& Weinstein, A. (2010). Compulsive buying. The american. Journal Of Drug And Alcohol Abuse, 36: 248-253. Doi:10.3109 / 00952990. 2010. 49359.

Nugroho, J. S. (2003). Perilaku konsumen: Konsep dan implikasi untuk strategi penelitian pemasaran. Jakarta: Prenada media.

Prakoso, S.A. (2013). Pengaruh pemanfaatan teknologi informasi, kelompok teman sebaya dan status sosial ekonomi orang tua terhadap perilaku konsumtif mahasiswa, (Skripsi) UNNES, Semarang.

Rahayu, E. (2018). Pengaruh e-service quality terhadap e-customer satisfaction dan e-customer loyalty pada toko online shopee (Studi kasus pada pengguna tokoonline shopee). (Skripsi). Universitas Islam Negeri Syarif Hidayatullah, Jakarta.

Rahayu, I. S. (2015). Minat nasabah menggunakan mobile banking dengan menggunakan kerangka Technology Acceptance Model (TAM) (Studi kasus pt bank syariah mandiri cabang Yogyakarta). Jurnal Ekonomi Syariah Indonesia, 5 (2): 137-150.

Rasimin. (1995). Manusia dalam industri dan organisasi. Yogyakarta: Gajah Mada University Press.

Rizkallah, E. G \& Truong, A. (2010). Consumptive behavior, promotional preferences, and shopping patterns of hispanic americans: an empirical perspective. Journal of Business \& Economics, 8 (4): 111-122.

Santrock, J.W. (2011). Remaja. Jakarta: Erlangga.

Sulistianingsih. (2016). Kecenderungan perilaku konsumtif mahasiswa sebagai bentuk gaya hidup shopaholic dan keterkaitannya dengan penyimpangan social. (Skripsi). Universitas Jember, Jember.
Sumartono. (2002). Terperangkap dalam iklan: Meneropong imbas pesan iklan televisi. Bandung: CV Alfabeta.

Syifa, L. (2019). Pengaruh kemudahan penggunaan mobile banking terhadap perilaku konsumtif mahasiswa FITK UIN Syarif Hidayatullah Jakarta. (Skripsi). Fakultas Ilmu Tarbiyah Dan Keguruan Uin Syarif Hidayatullah Jakarta.

Turban, E., Lee, J.K., King, D., Mc Kay, M. (2008). Electronic commerce: A managerial perspective. Upper saddle river: Pearson education inc.

Utami, A. H. (2006). Manajemen ritel strategi dan implementasi ritel modern. Jakarta: Erlangga.

Wulandari, Putri, N., Novandriani, N. \& Moeliono, K. (2017). Analysis of the factors of using mobile banking services. Business Administration: 139-149. 